\title{
Labour Reforms and Social Welfare: The Developmental Debate
}

\author{
Ranita Nagar*
}

\begin{abstract}
The much debated labour market reforms maintains the centre stage in the policy debate in India, caught in the vortex of the 'Make in India' campaign. The question posed by the author is how will labour law reforms address the concern of expanding employment and creating better quality employment for 78 percent of the work force in India, which do not fall within the ambit of labour laws and are classified as the unorganised sector. The second question posed is that if labour rigidities were an obstacle to increasing employment then reasons have to be traced for the significant increase in the share of contract workers in the total employment in the organised sector. Further if labour market rigidities were an obstruction, for employers to expand by hiring more workers, then the number of workers would have increased at least to a number less than 50 or 100 if the cause was to escape the implications of the labour laws since only numbers beyond this critical size of labour employed attract different laws to various degree. Thus to assess the complete picture, it is imperative to take a view of the interdependent drivers of growth like infrastructure, adequate power, access to credit etc. Most of all, the fact that more than 70 percent of workers in India earn marginal survival wage and are not protected by social security regulations, the proposed labour law reforms has the potential of increasing their vulnerabilities on account of the vagaries of globalisation.
\end{abstract}

Keywords: Labour law reforms; Wage rigidity; Organised and unorganised sector; Social security; Capital to wage ratio; Make in India.

\subsection{Introduction}

The 'Make in India' campaign has been envisaged as a program that will help to absorb the current levels of unemployment, absorb the backlog of unemployment and create employment for the significant additional workforce given the young demographic profile in India.

*Dean (Research), Gujarat National Law University, Gandhinagar, Gujarat, India. (Email id: rnagar@gnlu.ac.in) 
In line with this argument the existing labour laws have been identified as a regulatory rigidity and labour law reforms are being undertaken to reduce these so called identified constraints to employment expansion. In this discourse the fundamental concern guiding all reforms is whether India wants Economic growth or Economic development and the arguments in favour of labour law reforms need to be bound by this question.

The author in the paper will put the debate in perspective by building upon the following arguments. Government reports as well as different research studies state that the organised sector in India accounts for not more than 20 to 22 percent of the workers employed which leaves the 78 percent in the unorganised sector who are not bound by the labour laws. The question thus arises how will labour law reforms address the concern of expanding employment and creating better quality employment, meaning thereby employment at better wage rates for this 78 percent of the work force in India and more so in the manufacturing sector. If labour rigidities were an obstacle then reasons have to be traced for the significant increase in the share of contract workers in the total employment in the organised sector, as per Annual Survey of Industries which puts the increase from 15 percent to 26 percent from 2001 to 2011. The India Employment Report 2016 reflects that of the total employment figure in India, the organised sector accounts for a bare 17 percent. On the other hand, the lowest levels of the employment markets, which consist of the self-employed and the casual wage workers represent 78 percent of the employment. This is only possible given the fact that adequate flexibility already exists in the organised sector for employers to hire on contract terms which cleary is cost effective.

Further if labour market rigidities were an obstruction, for employers to expand by hiring more workers, then the number of workers would have increased at least to a number less than 100 , since only then the law becomes applicable, but data show that in most of the labour intensive establishments like garments, food products, tobacco, leather railway locomotive etc, 70 percent units have workers in the range of six to eight. These casual workers are paid a quarter of the wage paid to formalised workers. The OECD reports that in the manufacturing sector around $65 \%$ of jobs are in firms with less than 10 employees that is in the unorganised sector. To explain rigidities, the author explores the Industrial Dispute Act (IDA) of 1947, the Factories Act, Industrial Disputes Act, Apprentices Act and Contract Labour Act in order to understand the real nature of the wage rigidity and constraint on employment generation and the lack of social security for workers in terms of the popular debate and the counter arguments.

It would be incomplete to speak of Labour Laws as the significant cause behind the stagnated state of employment in the manufacturing sector. In order to assess the 
complete picture, it is imperative to take a view of the interdependent drivers of growth. like product market regulations, the environmental regulations, state of infrastructure, Land Acquisition, Rehabilitation and Resettlement Act, 2013, the rising capital intensity of production, import competition, production for the export market, the trade reforms, access to finance, tax reforms etc. The concern for great caution in undertaking reforms is highlighted both in India HDI and Inclusive growth rankings. The added dimension to this is the estimated addition of 300 million working age adults by 2040 as per the United Nation's report, 2009, given the backlog of surplus workers of 50 million, reported by The India Employment Report 2016.

The proposed reforms are a potential threat to the already marginal survival wage earnings of majority of Indian workers in the absence of social security cover and increasing vulnerabilities on account of the vagaries of globalisation (Labour Bureau, 2016) reports 85 percent of workers in India made an earning of less than 10,000 rupees per month. Labour reforms should be looking at the 78 percent workers in the unorganised sector and the 80 percent earning marginal survival wage rate by providing social security legislations, minimum wage etc. and thus address the issues of development and not growth per se.

Studies are indicating that some emerging economies, including China have gone back to strict regulations with regard to retrenching workers and are also providing increased social security benefits. This framework generates the famous adequate level of aggregate demand in the domestic market, the critical variable which contributes to sustainable growth in employment. In fact, affirmative state action can address the problems of market failure in the labour market because the debate is not of the rigid labour laws leading to shrinkage of employment but the reality of increasing contractual labour and its ramifications.

\subsection{India's Labour Reforms: The Popular Arguments and the Counters}

The composition and peculiarities of India's labour market has been an area of continuous interest among policymakers and researchers alike. India is known to enjoy a demographic advantage wherein almost 63 percent of the population is in the economically active group, i.e. in the working age group of 15-59 years. Further, according to a United Nations report, about one-fourth of the expected increase in global working age population between 2010 and 2040 will occur in India, reflecting the addition of 300 million in the work force. Presently, however, India is not able to exploit this demographic advantage completely, due to various factors affecting employment and productivity. One of the primary areas which is believed to have restricted 
investment and growth of employment in India is the area of labour reforms. It has been widely argued in literature that restrictive and rigid labour laws in India have discouraged investment in the country thereby also affecting employment (Ghose, 1995; Panagariya, 2007; Sood, Nath and Ghosh, 2014). In particular, investors and employers face hurdles with regard to hiring and firing of employees, trade unions and engaging of contractual labour, which have resulted in inflexibilities in the Indian labour market (Besley and Burgess, 2004 \& Dutta Roy, 2004).

Various government bodies and official reports have built up a case for 'second generation labour reforms' to do away with the rigidity in our labour regulations which make it difficult for employers and investors to respond to market changes and fluctuations. For instance, the Task Force on Employment Opportunities (2001) observed "the existing labour laws, and in particular the way they have been administered and implemented, have this unintended effect of opting for investing in capital intensive industries in favor of labour intensive ones. This has made India uncompetitive in these areas of export markets denying the possibility of large expansion in organised sector employment". Accordingly reports state that changes have been made by the Centre to the draft of the Factories Act, 1948, to allow states to decide on the number of workers a unit has to employ to be covered under the law thus giving flexibility to be exempt from the restriction.

Rajasthan has relaxed the provisions of the Factories Act, Industrial Disputes Act, Apprentices Act and Contract Labour Act whereas Madhya Pradesh has amended at least 20 labour laws, including the Industrial Disputes Act, Factories Act and Shops and Establishments Act. Interestingly, research conducted by (Upadhyaya, 2017) reflect diametrically opposite views coming from the representatives of the Chambers of commerce and the State Trade Union Federation regarding the impact of labour law reforms. The contribution of the industrial sector to Gross State Domestic Product in Rajasthan, post reforms, reduced from 30 percent in March 2009 to 28 percent in March 2015. The Government of Maharashtra, has issued a notification amending the Contract Labour (Regulation and Abolition) Act 1970. Previously this law was applicable to units having 20 or more workmen thus covering a larger number of establishments. Now, after the amendment, the law will apply to units having 50 or more employees which will significantly reduce the number of establishments covered by this law in the state.

The Central Government will pursue labour reforms by introducing two labour Bills in the Budget session ie, the Industrial Relations Code Bill 2016, which will make the process of hiring and retrenchment flexible and the Wage Code Bill, 2016 , according to which the central government will be in a position to fix a universal minimum wage. All establishments and workers will fall under this wage system. 


\subsection{The Rigidity of Labour Market Rigidities}

The main types of rigidities faced by the labour markets in India are with respect to wages, hiring and social security (Das et al. 2015)

a) Wage rigidity - Despite progressive liberalisation and economic reforms, rigidity in wage structure is said to remain a serious obstacle towards making labour market more market-oriented. It is argued that there are various imperfections in the labour market such as strong trade unions, wage setting and minimum wages as stipulated in various labour laws. These cause wages to be set at above market clearing levels, although this is largely restricted to the formal sector or organised labour market. The fact of weak enforcement of labour laws and absence of trade unions leaves the informal or unorganised sector largely unaffected by these regulations (Dutt, 2003). The counter is that labour market rigidities are a market failure which does not ensure socially efficient level of employment with its concurrent social and economic ramifications. This cost of ramification can be addressed by policy and law in the form of granting wage subsidies to labour intensive enterprises in a similar manner to the grant of subsidy to capital. The cost of this subsidy would be lower than the economic gains, both at the micro and macro levels.

b) Rigidity regarding retrenchment of workers - The argument forwarded is also that protective labour laws regarding hiring and firing of employees has made it extremely difficult for employers to retrench or lay-off workers or to adjust the quantity of labour employed in the production process in response to market conditions. About 4.5 million workers in factories with 100 or more workers have job security under Chapter V-B of the Industrial Disputes Act. The Act states that to retrench even a single worker, the firm has to seek the State's permission. This rigidity is said to be further accentuated by the presence of strong trade unions. Trade Unions fight bitterly against the imposition of fines and suspensions of their fellow workers, and often pressurise management not to engage in retrenchment of any sort. This legislation which ensures job security has come under much criticism from various quarters because this legislation curtails the freedom of employers to resort to the practice of "hire and fi re". It is argued that this rigidity has negatively impacted both output and employment growth since the market forces of demand and supply are not free to work and adjust themselves at the efficient levels. The argument that this rigidity has constrained establishments from achieving economies of scale because is an attempt to exempt themselves from this worker protecting legislation. There is no study that establishes the existing labour laws as the dominant cause restricting the growth of employment in the organised sector. The 
real constraints can be traced to multiple inefficiencies that have specified sectoral impacts, for example uninterrupted electricity in case of garment industry, improved roads, storage, access to finance in others. If labour law was the single most important factor then small enterprises (Sood, Nath and Ghosh, 2014) would have expanded employment from the present size of six to eight workers to a much larger numbe and might have chosen to limit expansion to just below hundred workers, the number at which the law would become applicable.

c) Social security - Though according to prevalent legislations the employer is required to compensate the worker in case of termination, the enforcement of such legislations is weak in the unorganised sector. It is only the minority in the working population that are adequately covered by this legislation and now even that minority will be made vulnerable by the much advocated labour law reforms. The concerns raised become more significant in view of the fact that there are no other alternative central government social security schemes or employment security in the formal segment of workers.

\subsection{The Enhanced Need for Social Security}

In the initial decades of planning, the social policy with regard to labour and employment in India, was to treat labour as a beneficiary of social and economic development. Since then and more so post globalisation, labour in India has become a mere resource for development (Das et al., 2015). The Nobel laureate, Amartya Sen, has strongly argued that labour is not the means of development but the ultimate goal of development is the development of labour. The capability approach has shown how through development the various capabilities of the individual is to be enhanced and this approach will automatically address the issues of improving India's Human development Index, attain inclusive growth which is also sustainable.

As was social security a necessity, post-independence, the need for social security becomes more critical in the face of the emerging scenarios like global slowdown, protectionist policies, and automation in the backdrop of India's demographic profile, unemployment, poverty and the issues of sustainable and inclusive growth. The World Bank data reflects that automation will create employment vulnerability in India to the extent of 69\% (World Bank Report 2016). As already mentioned, India's workingage population has increased by 300 million between 1991 and 2013, according to UN figures, but the number of people employed only rose by 140 million. As per The United Nations International Labour Organisation (ILO) World Employment and Social Outlook report 2017 "Unemployment in India is projected to increase from 17.7 million 
last year to 17.8 million in 2017 and 18 million next year". Though the Indian economy has attained growth in real GDP of 7.2 percent (Economic Survey, 2016-17), the employment rate has declined, the participation rate of women has declined by ten percent and stands at 27\%, the lowest among BRIC nations and job creation in the organised sector has plummeted since 2010 (OECD Economic Surveys: India, 2017). The more recent observations made by Professor Joseph Stiglitz and Professor Paul Krugman and Raghuram Rajan, expressing serious concerns about the problem of mass unemployment that India is poised to face, given that India needs to generate 12 million additional jobs per year. The fact that the jobs in the service sector will also shrink given the global export squeeze gives another dimension to the problem. The need for a more broad based and labor intensive employment policy is already much delayed and its impact on job creation in India is also more uncertain today given the use of artificial intelligence on one hand and global curtailment of markets on the other. The 'Inclusive Growth and Development Report 2017' shows the position of India as ranked $60^{\text {th }}$ among 79 developing economies, which shows a performance inferior to Pakistan in the Inclusive growth parameters. Conclusively the paradigm of growth leads to equity stands disapproved in the light of the fact that India shows acute inequality in income inspite of the fact that India's GDP is among the top ten highest growing economies in the developing world given that 80 percent of workers live on marginal survival wage rates. This reinforces the concern of strengthening the social security of Indian workers both in the organised and unorganised sector in order to attain the higher goal of development.

India has not adopted a national minimum social security cover as of now but Article 41 of Directive Principles requires the state to " within the limits of its economic capacity and development" make provision for right to livelihood and address vulnerabilities like unemployment, sickness, old age etc. (arts.36 to 51 of the Constitution of India, 1950). The main laws that have been enacted to provide social security benefits to workers in India are the Employees' Compensation Act, 1923; Employees' State Insurance (ESI) Act, 1948; Employees' Provident Funds and Miscellaneous Provisions Act, 1952; Maternity Benefit Act, 1961; and Payment of Gratuity Act, 1972. Studies have shown that these social security legislations fall below the standards recommended in the ILO Conventions. In an attempt to ensure social security cover to all workers, the Unorganised Workers Social Security Act, 2008 was enacted. This Act suffers from limitations like not including agricultural labourers, exclusion of the unorganized labourers in the organised sector and the informal labourers in the formal sector, exclusion of the anganwadi workers, para workers like ASHAs and parateachers, and those in the cooperative sector. The increasing problems of migrant workers are ignored, problems of women working in the unorganised sector 
also are not comprehensively covered by the Act. Thus labour market reforms should focus on providing the economic and social security of the workers and not make them more vulnerable.

\subsection{Labour Market: Organised versus Unorganised Sector and Contractual Labour}

The definition for the unorganised sector and informal workers has been given by The National Commission for Enterprises in the Unorganised Sector (NCEUS). According to this definition the unorganised sector comprise of "all unincorporated private enterprises owned by individuals or households engaged in the sale and production of goods and services operated on a proprietary or partnership basis and with less than ten workers". Informal are defined as "Informal workers consist of those working in the informal sector or households, excluding regular workers with social security benefits provided by the employers and the work".

The employment characteristics of the labour market in India cannot be sufficiently understood by looking at the sectoral composition alone, because of the presence of a large unorganised sector. From time to time, various studies have pointed out that a majority of the working population in India is employed in the informal sector (Ministry of Labour and Employment (2007-08); Harriss-White, 2003; De Neve, 2005) Interestingly, it has also been observed that since economic liberalisation, the formal sector has decreased in size, while simultaneously the informal sector has undergone a rapid and massive expansion (Chowdhury, 2007). Informal employment also covers those jobs that despite being located in sectors/enterprises traditionally seen as organised, are nevertheless not backed by any form of job security or social protection. Given this rapid and disproportionate increase in the informal sector, which doesn't have access to fundamental social security measures, it is highly unlikely that India will be able to reap the benefits of economic growth owing to its relatively large young workforce. More than 70 percent of the workforce in India at present are employed in the unorganised. Their contribution in the employment figures are critical and their contribution to India's National Income stands at 50 percent, inspite of their low levels of productivity (National Statistical Commission, 2012). It is also relevant to note that from 2004-5 to 2011-12, a rise in the proportion of employment is observed between the organised and unorganised sectors, ie from 13 to 17 percent but most of this rise came from the increase in the informal employment of the organised sector, ie from 48 percent to 55 percent accompanied by a decrease in the share of formal employment, from 52 percent to 45 percent from 2005 to 2011 . The share of contract workers in organised manufacturing sector has increased substantially from 13 percent in 1995 to 34 per cent in 2011 (India Labour and Employment Report 2014). 
The workers or employees in the formal or organised manufacturing sector are protected by various legislations governing their minimum wages, protection, and social security payments. They enjoy greater entitlements and benefits than workers in the unorganised sector. Many laws protect and promote the interests of workers employed in this sector - like their health, wages, safety, and minimum timely payment, maternity leave for women, bonus, provident fund, and gratuity. In welfare terms, formal sector workers in India are both labour market and welfare insiders, given that they receive full employment and social security benefits. In comparison, those individuals in the informal sector are labour market and welfare outsiders, since they have access to only minimal employment and social security benefits. Informal workers in organised enterprises are more often than not excluded from the scope of regulations stipulating conditions of work, retrenchment and minimum wages that are applicable to their formal counterparts (Sood, Nath and Ghosh 2014). A growing amount of literature points towards the fact that employers in formal manufacturing in India are successfully circumventing the inflexibility posed by laws like the Industrial Dispute Act 1947 by resorting to employing contract workers who are not bound by the major labour laws (Kapoor, 2014; Chaurey, 2015) and thus take the benefit of retrenching workers in the face of volatile markets in an attempt to sustain supernormal profits.

Contract workers and their employment are regulated by the provisions of the Contract Labour Act (CLA) 1970. The recent judicial interpretations of the Contract Labour Act in the 2000s in favour of principal employers have actually led to reforms making the labour market more flexible (Das et al. 2015). While this may be the case, it needs to be understood that such workers, in turn, can also leave at will, thereby affecting attrition rate. There may also be social costs of such a trend in that such workers may not stay long enough to gain skills, leading to a shortage of skilled workforce. This is particular detrimental in a country like India whose competitive advantage lies in its skilled human resources. Thus, contract labour may be good for relatively unskilled work but not for skilled jobs which require the employee to stay for a relatively longer time period.

\subsection{Social Welfare Dimension of Labour Reforms}

One of the arguments for labour reforms rests on the ground such reforms would actually lead to more workers being formalised. As seen above, employers have a preference for informal or unorganised labour as it reduces their costs and helps them to circumvent the strict labour regulations applicable to the organised labour. However, a counter view is that it seems unlikely that employers would stop 'informalising' labour 
unless formal labour became just as cheap (in terms of their conditions and pay) as the informal ones. In fact, what has been observed in recent years is that even with the present reforms, the share of informal workers has actually gone up (Lerche, 2015).

While flexible labour laws are being forwarded, there is a need to examine the social welfare dimension of the proposed flexibility. As seen above, the vast majority of informal labour falls outside the ambit of most of the social security provisions. The lack of welfare provision not only affects informal sector workers and their families, but also has wider implications for the economy and society at large. From an economic perspective, it adversely affects the informal sector worker's ability to engage in the labour market and positively contribute to and participate in the economy in a productive manner. This inability, combined with inadequate wages and vulnerabilities such as poor health and educational attainment, can lead to extreme economic poverty, which in turn affects the economy in general by reducing the aggregate demand for goods and services.

The laws relating to firing of workers, which is the main contentious issue with regard to labour market reforms, are presently structured in such a way that employers have to bear the risk. This, in turn, pushes them to engage in large scale contract labour hiring. Keeping in mind the social welfare of our human resources, the society as a whole needs to bear the burden of protection and safety of workers. Issues such as unemployment insurance and re-absorption of displaced contract workers (in times of negative market shocks) are important issues that need to be talked about in relation to labour markets of India.

\subsection{Labour Reforms in Context of 'Make in India' Campaign}

The Make in India initiative announced officially in September 2014, aims to attain increased investment, rapid innovation by protecting intellectual property, boost skill development through training, create business friendly regulations by reducing all possible transaction costs, build good infrastructure, undertake substantial labour law reforms and convert India into a manufacturing hub of the world (CII, p.23).

However, the reforms going through parliament right now are facing controversies for three main reasons (Lerche, 2015):

1) It may become easier to lay off workers on account of the changes made in the Industrial Disputes Act (IDA) by which it was not possible for employers to dismiss workmen in factories employing 300 workers or more but now the applicable threshold of workers has been reduced to 100. In the light of the problems being faced by 
manufactureres in the wake of GST, there is a strong incentive to lay off workers in order to manage the the issues of profitability which is leaving workers more vulnreable. 2) The upper limit for informal factories will now be raised to 20 workers and factories below this threshold will be exempt from 14 labour laws, which include laws dealing with occupational safety, health and welfare of workers. This would imply deregulation of many small factories and jeopardising the interests and safety of many workers in the process. This problem is more pronounced in the face of global slowdown, demonetisation, GST and falling GDP figures in India.

3) The provisions have made the requirements for trade unions to be registered difficult by increasing the required membership from 15 percent of the total workforce to 30 percent taking away the possibility of the workers to organize and demand for their rights increasing their vulnerability.

The 'Make in India' policy of the Government of India (2014) attempts to place the manufacturing sector on a higher growth path, and is believed by many to be a step in the right direction (Kapoor, 2014, p.25). It sends signals to investors and employers that the central government is keen to create a conducive environment for the manufacturing sector to flourish. The recent reports however reveal that indicators like the increase in the FDI flow actually do not reveal the true picture because this increase in FDI must be seen from a sector specific perspective. Reports reveal that the FDI in certain core manufacturing sectors show a reduction whereas in most cases, a very small percentage of the FDI growth is reflected in the core manufacturing sectors. The impact of FDI also need closer scrutiny based on the tenets of the net addition to fresh domestic capacities and net addition of capital as a result of the Make in India policy (Rao and Dhar, 2016). Employment figures are also at an all-time low across the Indian economy and more so in the manufacturing sector. Thus the discourse on labour law reforms needs to be focussed towards the social welfare aspect of all stakeholders, particularly the contract workers and not creating further possibilities of layoffs and restrictions of rights.

\subsection{Conclusion}

The argument behind the 1991 economic reforms was that the reforms in the industrial and trade sector would absorb much of the surplus labour trapped in the stagnant agriculture sector, by developing the labour intensive industries. The reforms took place in the product market and capital market by way of deregulation. This resulted in a fall in labour intensity from 3.34 percent in 1980 to 0.78 percent in 2010. The 1991 reforms led to significant decrease in the price of capital on account of the reduction in import tariffs. Thus the reduction in ratio of wage to rental price of capital 
displaced labour in favour of capital, leaving the question of expanding productive employment, by and large inadequately answered.

The dominant argument that labour market deregulation are an important path to reducing unemployment and boosting growth need to be revisited on the lines of conclusive studies which adequately prove the same. As mentioned, the labour reforms, per se will not lead to expansion in employment but lead to further circumvention of social security provisions for workers. Most importantly any introduction of flexibility with regard to various labour provisions such as wages and firing, must simultaneously be accompanied by welfare and social security provisions of the workforce. There have been examples of strong welfare state provisions having been associated with falling unemployment. For instance, Denmark and Sweden, have high standards of labour regulation and worker protection than US, and they have still performed better than US in terms of employment.

Canada over the 1990s implemented various reforms of the labour market in order to attain greater flexibility, which led to more job insecurity and reduced bargaining power of workers. As a consequence, the worker participation rates and employment generation started falling. Keeping this in mind, many countries, including some developing countries are now strengthening their labour laws in order to improve the work and wage conditions by granting rights to their workforce. The 2016, Doing Business report states that under regulation in terms of minimum wage and wage hours negatively affects the work productivity. Thus Labour law in India should be seen as a mechanism to enhance efficiency, increase employment while considering both the economic as well as social welfare dimension of reforms.

The potential of growth in an economy, is unleashed by the forces of market, technology, innovations and the law and policy framework. The cumulative forces of growth can be understood by examples of countries who have performed exponentially better than others, in terms of the growth in their per capita income. Tracing the history of 56 countries in 1820 (Angus Maddison, The World Economy: A Millennial Perspective, Development Center of OECD) shows that the difference between the richest and the poorest countries was to a ratio of $4: 1$ whereas a similar study undertaken by Schafer and Cooter, Solomon's Knot: How Law Can End the Poverty of Nations for the year 2003 found the ratio to stand at 50:1. This possibility has been attained by ensuring that labor laws are such that they address all market failures possible in the job market, the biggest being the widening gap in the supply of labor as against the aggregate demand. The associated rigidities or obstacles in the addressing the market failures with regard to innovations and technology are addressed by similar progressive and value enhancing legislations. It would be an area of further research to 
42 | PRAGATI: Journal of Indian Economy, Volume 4, Issue 2, Jul-Dec 2017

study the role of labor laws, in particular, in the countries that exponentially gained to their advantage and increased their per capita income from the ratio of 4 to 50 .

\section{References}

Besley, T. \& Burgess, R. (2004). Can labour regulations hinder economic performance? Evidence from India. Quarterly Journal of Economics, 119 (1), 91- 134.

Chaurey, R. (2015). Labour regulations and contract labour use: Evidence from Indian firms. Journal of Development Economics, 114, 224-232.

Chowdhury, R. (2007). Globalization and labour. In Nayar, B.R. (Ed.), Globalization and Politics in India (pp. 517-526). New Delhi: Oxford University Press.

Das, S., Jain-Chandra, S., Kochhar, K., \& Kumar, N. (2015). Women workers in India: Why so few among so many? IMF Working Paper No. 15/55. Retrieved from https://ssrn.com/abstract=2594138

De Neve, G. (2005). The everyday politics of labour, working lives in India's informal economy. New Delhi: Social Science Press.

Dutt, P. (2003). Labour market outcomes and trade reforms: The case of India. In R. Hasan and D. Mitra (Eds.), The Impact of Trade on Labour: Issues, Perspectives, and Experiences from Developing Asia (pp. 1-45).Amsterdam: Elsevier.

Dutta Roy, S. (2004). Employment dynamics in Indian industry: Adjustment lags and the impact of job security regulations, Journal of Development Economics, 73(1), 233-256. Ghose, A. K. (1995). Labour market flexibility and the Indian economy. Indian Journal of Labour Economics, 38(1), 55-62.

Harriss-White, B. (2003). India working: Essays on society and economy (Vol. 8). Cambridge, UK: Cambridge University Press.

Kapoor, R. (2014). Creating good jobs: Assessing the labour market regulation debate. Economic and Political Weekly, 49(46), 16-18.

Lerche, J. (2015). Making India? The labour law reforms of Narendra Modi's government. South Asia Notes, SOAS South Asia Institute Blog. 
Ministry of Labour \& Employment. Report on Fifth Annual Employment Unemployment Survey (2015-16) Volume I. Retrieved from http://labourbureaunew.gov.in/UserContent/EUS_5th_1.pdf

Ministry of Labour and Employment, GOI. (2007-08), Annual Report 2007-08 (New Delhi: Government of India). Retrieved from http://labour.nic.in/annrep/ annrep2007.htm

National Statistical Commission. (2012). Report of the Committee on Unorganized Sector Statistics. Retrieved from http://www.lmis.gov.in/sites/default/files/NSC-reportunorg-sector-statistics.pdf

OECD. (2017). Overview of the Economic Survey of India: Strong growth has raised incomes and reduced poverty, but challenges remain. Retrieved from http://www.oecd.org/india/economic-survey-india.htm

Panagariya, A. (2007). Why India lags behind China and how it can bridge the gap. The World Economy, 30(2), 229-248.

Sood, A., Nath, P., \& Ghosh, S. (2014). Deregulating capital, regulating labour: The dynamics in the manufacturing sector in India. Economic and Political Weekly, 49(26\&27), 58-68.

Upadhyaya, S. (2017). Amendments in labour laws and other labour reform initiatives undertaken by State Governments of Rajasthan, Andhra Pradesh, Haryana and U.P. An Analytical Impact Assessment. Retrieved from http://www.vvgnli.gov.in/sites/ default/files/ 122-2017\%20-\%20Sanjay\%20Upadhyaya.pdf 